\title{
Analysis of Satisfaction Relationship Model and Customer Loyalty in Marketing Smartphone Brand X
}

\author{
Minto Waluyo* \\ Industrial Engineering Department, \\ Faculty of Engineering \\ $U P N$ "Veteran Jawa Timur \\ East Java, Indonesia \\ mintow.ti@upnjatim.ac.id
}

\author{
Nur Rahmawati \\ Industrial Engineering Department, \\ Faculty of Engineering \\ UPN "Veteran Jawa Timur \\ East Java, Indonesia \\ nur.rahma.ti@upnjatim.ac.id
}

\author{
Kinanti Resmi Hayati \\ Industrial Engineering Department, \\ Faculty of Engineering \\ UPN "Veteran Jawa Timur \\ East Java, Indonesia \\ kinantihayati.ti@upnjatim.ac.id
}

\author{
Mohammad Rachman Waluyo \\ Industrial Engineering Department, \\ Faculty of Engineering \\ UPN "Veteran Jakarta \\ Jakarta, Indonesia \\ aanvicenzo@gmail.com
}

\begin{abstract}
Smartphone Brand $\mathrm{X}$ is one of the smartphone brands from China which in the third quarter of 2019 had the second largest market share in Indonesia and it surprised competitors and consumers. The researcher made a model to measure customer satisfaction and loyalty towards users of the Brand X Smartphone products. The aim of this study is to determine the factors that influence satisfaction with the brand smartphone customer loyalty. The research method uses Structural Equation Modeling (SEM) tools, collecting data based online with the Google Form sample platform collected as many as $\mathbf{1 7 0}$ by conducting two stages of the Measurement and Structural Model tests. The results show that brand image on customer satisfaction has a negative effect and not significant (est. Std. Regression weight $=\mathbf{- 0 . 1 6 8}$ ). Price perception on customer satisfaction also has a positive effect but not significant (est. Regression weight $=\mathbf{0 . 2 0 8}$ ), product quality on customer satisfaction has a positive effect too and not significant (est. Std. Regression weight $=0.541$ ). ecommerce on customer satisfaction has a positive effect but not significant effect (est. Std. Regression weight $=\mathbf{0 . 4 0 3}$ ). Interpersonal communication on customer satisfaction has a positive effect and not significant (est. Std. Regression weight = 0.434). Customer satisfaction on customer satisfaction has a positive effect and not significant with (est. Std. Regression weight $=0.890$ ).
\end{abstract}

Keywords: Brand Image, Price Perception, Product Quality, E-commerce, Interpersonal Communication, Customer Satisfaction, Customer Loyalty, SEM

\section{INTRODUCTION}

The current communication technology in Indonesia is currently experiencing a very rapid development.With this huge market potential, several branded smartphone players have begun to expand the Indonesian market such as Samsung, Apple, Oppo, Lenovo, Xiaomi and others. A unique anomaly occurs in a smartphone brand $\mathrm{X}$ which is a product of a Chinese private electronics company. From the first quarter of 2016 to the third quarter of 2019, based on data compiled from the Global Statistics Counter website, the market share of Chinese smartphone products is in the second position of $22.67 \%$ which only has a slight difference with the rulers of the electronic market in Indonesia such as Samsung with a market share of $25.11 \%$.

For this reason, this study aims for modeling factors which influence the success of smartphone brand $\mathrm{X}$ manufacturers. Departing from this uniqueness problem, researchers measured the factors that influence satisfaction with customer loyalty to smartphone users. The model designed focuses on brand image factors, price perceptions, product quality, e-commerce, and interpersonal communication as exogenous variables and these variables are generally used to measure customer satisfaction, for endogenous variables customer satisfaction and loyalty. In this paper will use the Structural Equation Modeling (SEM) method. Research with similar topics has been carried out beforehand among them (Jiang and Zhang, 2016) which conducted research on airline users in China, on automobile service users (Izogo, E. et al., 2015), on retail customers (Neupane, 2015), on Islamic bank consumers in Malaysia (Kashif, et al., 2015), on user's health services (Lonial and Raju., 2015), as well as online shop users ( $\mathrm{Wu}, \mathrm{M}$. Y and Tseng, L. H, 2015)

Structural Equation Modeling (SEM) was chosen because SEM is a multivariate analysis technique which is a combination of path analysis, factor analysis, regression analysis, and structural models. Several previous studies have also used SEM (Del Giudice and Della Peruta, 2016), including using SEM to determine the effect of management systems of IT-based knowledge on innovation and internal venturing (Elkaseh, A, et al, 2016) using SEM to find out perceptions of the ease and usefulness of social media for elearning in higher education in Libyan (Chin, W. Et al, 2008) used SEM to create a marketing model (Gau, J., 
2010) used SEM to model criminal justice and criminology (Xiong, Y et al, 2015). used SEM to test the relationship between student motivation, engagement, and retention in the Massive Open Online Course (Ockey, G. J and Choi, I., 2015) used SEM for language assessment (Tan, L. P and Wong, K. Y, 2015) used SEM to find out the link between manufacturing performance and knowledge management (Tarhini, A et al, 2017) used SEM to find out the factors that influence students who adopt e-learning (Alrowwad, A. et al, 2017) used SEM to know the transformational leadership impact on organizational performance. The model produced in this study later can be used as a measurement guideline in making marketing strategies in the next quarters.

\section{METHOD}

This research used Structural Equation Modeling (SEM) method to analyse the problems. Questionnaire distribution is done online based on the googleform platform using Linkert scale (1-5). Data processing uses two stages measurement model which is intended to confirm a dimension or factor based on its empirical indicators. Furthermore the structural measurement model discusses the structure of relationships that shape or explain causality between constructs. The questionnaire collection data obtanined 170 respondents who met the criteria a number of data is sufficient maximum likelihood (100-200)..

\section{RESULT AND DISCUSSION}

\section{A. Measurement Model Test}

Measurement model test is a test carried out on each model of measurement, related to the relationship between manifest variables and latent variables, the aim is to find out how precisely manifest variables (indicators) can explain existing lanten variables, the basis of measurement of validity ( $\mathrm{CR}>2 \mathrm{SE}$ ) and significant $<0.05$, results of Measurement Test models as in the table below.

Table 1. Validity, significant and standardized regression weight Measurement Model.

\section{B. Structural Model Test}

All Variable are valid except for Y1 X1 and probability $\mathrm{P}>0.5$ all variable is not significant, but all variable have direct effect ecxept Y1 X1

\begin{tabular}{|c|c|c|c|c|c|c|c|c|}
\hline & Estimate & S.E. & $C R$. & 2.SE & p & Kat. Valid & Ket. Signifikan & $\begin{array}{c}\text { Estimate } \\
\text { Standardized } \\
\text { Regression } \\
\text { Weight }\end{array}$ \\
\hline $\mathrm{X} 2.4<\ldots \mathrm{X} 2$ & 1 & & & & & & & 0,359 \\
\hline $\mathrm{X} 2.3<\ldots \mathrm{X} 2$ & 0,856 & 0,371 & 2,308 & 0,742 & 0,021 & Valid & Signifikan & 0,289 \\
\hline $\mathrm{X} 2.2<\ldots \mathrm{X} 2$ & 1,3 & 0,536 & 2,425 & 1,072 & 0,015 & Valid & Signifikan & 0.395 \\
\hline $\mathrm{X} 2.1<\ldots \mathrm{X} 2$ & 1,679 & 0,017 & 2,721 & 1,234 & 0,007 & Valid & Signifikan & $\overline{0,502}$ \\
\hline $\mathrm{X} 3.7<\ldots \mathrm{X} 3$ & 1 & & & & & & Signifikan & 0,254 \\
\hline $\mathrm{X} 3.6<\ldots \mathrm{X} 3$ & 1,338 & 0,551 & 2,427 & 1,102 & 0,015 & Valid & Signifikan & 0,387 \\
\hline $\mathrm{X} 3.5<\ldots \mathrm{X} 3$ & 1,762 & 0,648 & 2,718 & 1,296 & 0,007 & Valid & Signifikan & 0,507 \\
\hline $\mathrm{X} 3.4<\ldots \mathrm{X} 3$ & 1,635 & 0,643 & 2,542 & 1,286 & 0,011 & Valid & Signifikan & 0,404 \\
\hline $\mathrm{X} 3.3<\ldots \mathrm{X} 3$ & 1,438 & 0,587 & 2,448 & 1,174 & 0,014 & Valid & Signifikan & 0,378 \\
\hline $\mathrm{X} 3.2<\ldots \mathrm{X} 3$ & 1,024 & 0,442 & 2,32 & 0,884 & 0,02 & Valid & Signifikan & 0,322 \\
\hline $\mathrm{X}_{3} .1<\ldots \mathrm{X} 3$ & 1,158 & 0,537 & 2,156 & 1,074 & 0,031 & Valid & Signifikan & 0,286 \\
\hline $\mathrm{X} 4.9<\mathrm{X} 4$ & 1 & & & & & & Signifikan & 0,434 \\
\hline $\mathrm{X} 4.8<\ldots \mathrm{X} 4$ & 0,839 & 0,241 & 3,488 & 0,482 & 604 & Valid & Signifikan & 0,367 \\
\hline $\mathrm{X} 4.7<\ldots \mathrm{X} 4$ & 0,092 & 0,224 & 3,081 & 0,448 & 0,002 & Valid & Signifikan & 0,313 \\
\hline $\mathrm{X} 4.6<\mathrm{X} 4$ & 0,258 & 0,203 & 1,268 & 0,406 & 0,205 & Valid & Tidak Signifikan & 0,116 \\
\hline $\mathrm{X} 4.5<\ldots \mathrm{X} 4$ & 1,5 & 0,348 & 4,312 & 0,696 & 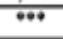 & Valid & Signifikan & 0,679 \\
\hline $\mathrm{X} 4.4<\ldots \mathrm{X} 4$ & 0,534 & 0,212 & 2,515 & 0,424 & 0,012 & Valid & Signifikan & 0,262 \\
\hline $\mathrm{X} 4.3<\mathrm{X} 4$ & 0,773 & 0,24 & 3,219 & 0,48 & 0,001 & Valid & Signifikan & 0,381 \\
\hline $\mathrm{X} 4.2<\ldots \mathrm{X} 4$ & 0,958 & 0,243 & 3,939 & 0,486 & $\Leftrightarrow 4$ & Valid & Signifikan & 0,456 \\
\hline $\mathrm{X} 4.1<\ldots \mathrm{X} 4$ & 0,833 & 0,244 & 3,415 & 0,488 & 604 & Valid & Signifikan & 0,379 \\
\hline $\mathrm{X} 5.4<\ldots \mathrm{X} 5$ & 1 & & & & & & Signifikan & 0,226 \\
\hline $\mathrm{X} 5.3<\ldots \mathrm{X} 5$ & 2,408 & 1,035 & 2,328 & 2,07 & 0,02 & Valid & Signifikan & 0,535 \\
\hline $\mathrm{X} 5.2<\ldots \mathrm{X} 5$ & 2,618 & 1,131 & 2,315 & 2,262 & 0,021 & Valid & Signifikan & 0,595 \\
\hline $\mathrm{X} 5.1<\ldots \mathrm{X} 5$ & 2,255 & 0,938 & 2,403 & 1,876 & 0,016 & Valid & Signifikan & 0,497 \\
\hline $\mathrm{X} 1.3<\ldots \mathrm{X} 1$ & 1 & & & & & & Signifikan & 0,357 \\
\hline $\mathrm{X} ! .2<\cdots \mathrm{X} !$ & 0,734 & 0,328 & 2,242 & 0,656 & 0,025 & Valid & Signifikan & $0,25 !$ \\
\hline $\mathrm{X} 1.1<\ldots \mathrm{X} 1$ & 1,339 & 0,461 & 2,901 & 0,922 & 0,004 & Valid & Signifikan & 0,512 \\
\hline $\mathrm{Y} 1.1<\ldots Y !$ & 1 & & & & & & Signifikan & 0,071 \\
\hline $\mathrm{Y} 1.2<\mathrm{Y} 1$ & 8,494 & 12,898 & 0,659 & 25,796 & 0,51 & Tidak Valid & Tidak Siznifikan & 0,67 \\
\hline $\mathrm{Y} 1.3<\ldots \mathrm{Y}$ & 8,073 & 11,918 & 0,677 & 23,836 & 0,498 & Tidak Valid & Tidak Signifikan & 0,581 \\
\hline$Y 2.4<\ldots Y 2$ & 1 & & & & & & & 0,078 \\
\hline $\mathrm{Y} 2.3<\ldots \mathrm{Y}$ & 3,234 & 2,175 & 1,487 & 4,35 & 0,137 & Tidak Valid & Tidak Signifikan & 0,234 \\
\hline$Y 2.2<\ldots Y 2$ & 1,351 & 0,971 & 1,392 & 1,942 & 0,164 & Tidak Valid & Tidak Siznifikan & 0,111 \\
\hline$Y 2.1 \ll Y 2$ & 0,659 & 0,71 & 0,928 & 1,42 & 0,353 & Tidak Valid & Tidak Signifikan & 0,056 \\
\hline
\end{tabular}




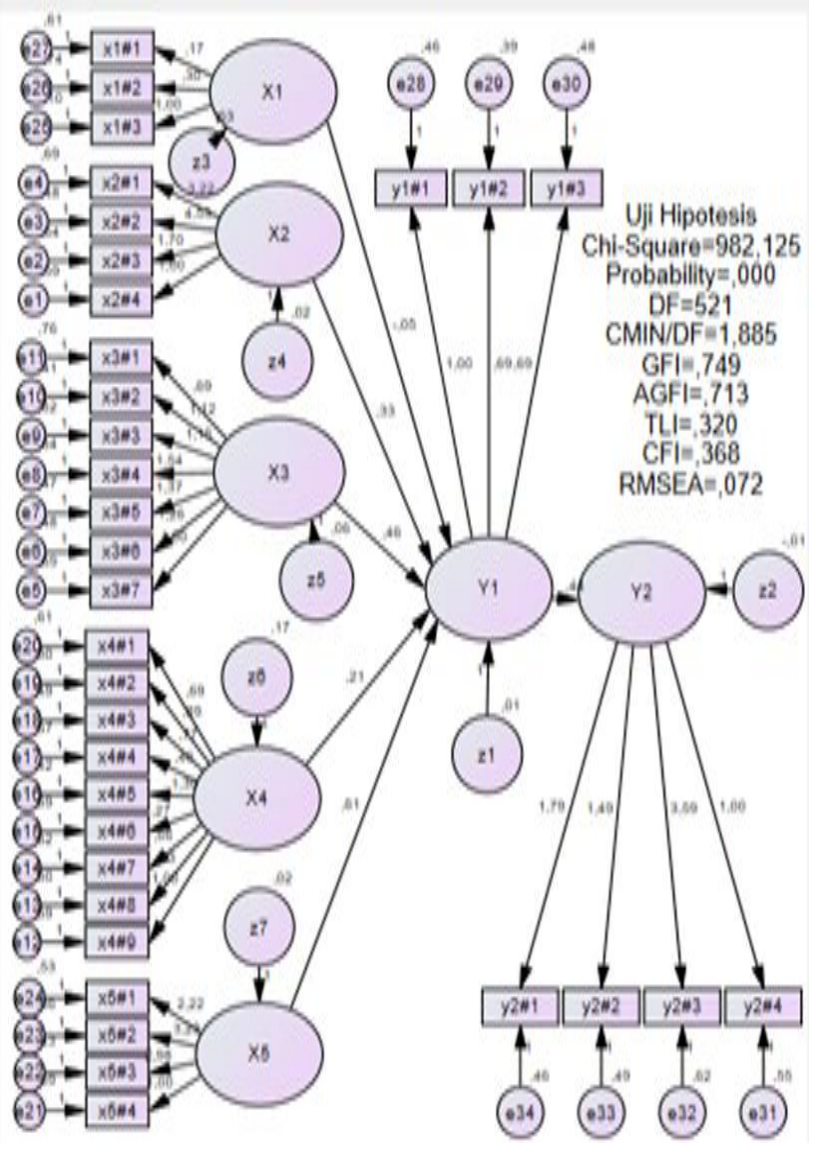

Table 2. Validity, significant and standardized regression weight Structural Model

\section{Hypothesis Analysis}

H1: Brand image has a significant relationship to the satisfaction of customer

Data from the hypothesis test results are presented in Table 2. From this table it can be seen that HO is accepted which means Brand Image (X1) does not have a significant effect on Customer Satisfaction (Y1).

$\mathrm{H} 2$ : Price perception has a significant relationship to customer satisfaction

Data from the hypothesis test results are presented in Table 2. From this table it can be seen that $\mathrm{HO}$ is accepted which means Price Perception Price (X2) does not even have a significant effect on customer satisfaction (Y1).

H3: Product quality has a significant influence relationship to customer satisfaction

Data from the hypothesis test results are presented in Table 2. From this table it can be seen that $\mathrm{H} 0$ is accepted, which means product quality (X3) does not have a significant effect on customer satisfaction (Y1).

H4 : E-commerce has a significant influence relationship to the satisfaction of customer

Data from the hypothesis test results are presented in Table 2. From this table it can be seen that HO is accepted which means E-commerce (X4) does not have a significant effect on customer satisfaction (Y1).

H5: Interpersonal communication has a significant influence relationship to customer satisfaction

\begin{tabular}{|c|c|c|c|c|c|c|c|c|}
\hline & Ditmote & SE & $C R$ & 288 & 1 & Re Valid & Re Siginitous & 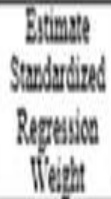 \\
\hline $11<\mathrm{s} / \mathrm{X3}$ & 0,430 & 0,285 & 1,611 & 0,5 & 0,107 & Vad & Thersingibu & 0,44 \\
\hline 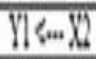 & 0.331 & 0,318 & 1,043 & 0,630 & 0.291 & Vadd & Tharsigentom & 0,028 \\
\hline $11<\ldots \times 4$ & 0.111 & 0.121 & 1,245 & 0.24 & 0,081 & $\sqrt{\text { Wad }}$ & 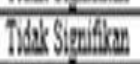 & 0,403 \\
\hline $118, \ldots \times 18$ & 0,008 & 0,481 & $1,1,64$ & 0,042 & 0,206 & Tald & 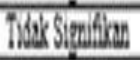 & 0,434 \\
\hline 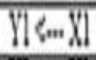 & 1,0,45 & 0,068 & 0,664 & 0,136 & 0,507 & 7620 & Thas sientifou & 0,0168 \\
\hline 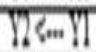 & 0,498 & 0,393 & 1,82 & 0,086 & 0. & Varid & 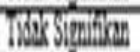 & 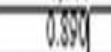 \\
\hline
\end{tabular}

Data from the hypothesis test results are presented in Table 3. From this table it can be seen that HO is accepted which means Interpersonal Communication (X5) has a positive effect but not significant on customer satisfaction (Y1).

H6: Customer satisfaction has a significant relationship to the loyalty of customer

Data from the hypothesis test results are presented in Table 3. From this table it can be seen that $\mathrm{H} 0$ is accepted, which means customer satisfaction (Y1) does not have a significant effect on customer loyalty (Y2).

\section{CONCLUSION}

The results of the analysis and discussion can be concluded, that the Factors Affecting Satisfaction toward Customer Loyalty Smartphone brand $\mathrm{X}$ include: Brand Image (X1) does not significantly influence Customer Satisfaction (Y1), Price Perception (X2) does not effect significantly on customer satisfaction (Y1), product quality (X3) does not effect significantly on customer satisfaction (Y1), E-commerce (X4) does not have an effect significantly on customer satisfaction (Y1), Interpersonal communication (X5) also has a positive effect but not significant on customer satisfaction (Y1) and customer satisfaction (Y1) has a positive effect but not significant on customer loyalty (Y2). To test the model produces. Goodness of Fit and Cutoff Value are Chi-square $=982.125$, Probability level $=$ $0.0003, \mathrm{df}=521 \mathrm{Cmin} / \mathrm{df}=1.885, \mathrm{RMSEA}=0.72, \mathrm{GFI}=$ $0.749, \mathrm{AGFI}=0.713, \mathrm{CFI}=0.368, \mathrm{TLI}=0.320$.

\section{ACKNOWLEDGMENT}

This research was held to fulfill the second point of tridharma as requirement for lectures. Thanks to UPN "Veteran" Jawa Timur and all the colleagues for their contribution to this research. This research was dedicated for academic purposed especially in industrial engineering department. 


\section{REFERENCES}

[1] Alrowwad, A. A., Obeidat, B. Y., \& Aqqad, N. (2017). The impact of transformational leadership on organizational performance via the mediating role of corporate social responsibility: A structural equation modeling approach. International Business Research, 10(1), 199-221.

[2] Chin, W. W., Peterson, R. A., \& Brown, S. P. (2008). Structural equation modeling in marketing: Some practical reminders. Journal of marketing theory and practice, 16(4), 287-298.

[3] Del Giudice, M., \& Della Peruta, M. R. (2016). The impact of IT-based knowledge management systems on internal venturing and innovation: a structural equation modeling approach to corporate performance. Journal of Knowledge Management.

[4] Elkaseh, A. M., Wong, K. W., \& Fung, C. C. (2016). Perceived ease of use and perceived usefulness of social media for e-learning in Libyan higher education: A structural equation modeling analysis. International Journal of Information and Education Technology, 6(3), 192.

[5] Gau, J. M. (2010). Basic principles and practices of structural equation modeling in criminal justice and criminology research. Journal of Criminal Justice Education, 21(2), 136-151.

[6] Izogo, E. E., \& Ogba, I. E. (2015). Service quality, customer satisfaction and loyalty in automobile repair services sector. International Journal of Quality \& Reliability Management.

[7] Jiang, H., \& Zhang, Y. (2016). An investigation of service quality, customer satisfaction and loyalty in China's airline market. Journal of air transport management, 57, 80-88.

[8] Kashif, M., Shukran, S. S. W., Rehman, M. A., \& Sarifuddin, S. (2015). Customer satisfaction and loyalty in Malaysian Islamic banks: a PAKSERV investigation. International Journal of Bank Marketing.

[9] Lonial, S., \& Raju, P. S. (2015). Impact of service attributes on customer satisfaction and loyalty in a healthcare context. Leadership in health Services.

[10] Neupane, R. (2015). The effects of brand image on customer satisfaction and loyalty intention in retail super market chain UK. International Journal of Social Sciences and Management, 2(1), 9-26.

[11] Ockey, G. J., \& Choi, I. (2015). Structural equation modeling reporting practices for language assessment. Language Assessment Quarterly, 12(3), 305-319.

[12] Tan, L. P., \& Wong, K. Y. (2015). Linkage between knowledge management and manufacturing performance: a structural equation modeling approach. Journal of knowledge management.

[13] Tarhini, A., Al-Busaidi, K. A., Mohammed, A. B., \& Maqableh, M. (2017). Factors influencing students' adoption of e-learning: a structural equation modeling approach. Journal of International Education in Business.

[14] Wu, M. Y., \& Tseng, L. H. (2015). Customer satisfaction and loyalty in an online shop: An experiential marketing perspective. International Journal of Business and Management, 10(1), 104.

[15] Xiong, Y., Li, H., Kornhaber, M. L., Suen, H. K., Pursel, B., \& Goins, D. D. (2015). Examining the relations among student motivation, engagement, and retention in a MOOC: A structural equation modeling approach. Global Education Review, 2(3), 23-33 